Bidik: Jurnal Pengabdian kepada Masyarakat | Vol. 2 No. 1 Oktober 2021

Doi: https://doi.org/10.31849/bidik.v2i1.8189

\title{
Pelatihan Manajemen Seni Pertunjukan kepada Komunitas Seni Kesara
}

\author{
Jefrizal*, Ridwan, Deni Afriadi \\ Prodi Sastra Daerah, Fakultas Ilmu Budaya, Universitas Lancang Kuning \\ *Email: jefrizal@unilak.ac.id
}

\begin{abstract}
The purpose of this training activity is (1) to provide an understanding of the stages of managing a show or event. (2) So that the event can be walk on the planned. To achieve this, training activities are needed including (1) Providing performing arts management materials, (2) Assisting partners and to be bolding Komunitas Kesara that will launch a poetry musical album.
\end{abstract}

Keywords: Performing Arts Management, Kesara, Training.

\begin{abstract}
Abstrak
Tujuan dari kegiatan pelatihan ini adalah (1) memberikan pemahaman tahap-tahap dari memenej sebuah pertunjukan atau acara. (2) Agar acara yang digelar, dapat berjalan sesuai dengan yang direncanakan. (3) Untuk mencapai ini, maka diperlukan kegiatan pelatihan meliputi (1) Memberikan materi manjemen seni pertunjukan, (2) Mendampingi mitra yang kebetulan akan menggelar acara peluncuran album musikalisasi puisi.

Kata Kunci: Manajemen Seni Pertunjukan, Kesara, Pelatihan.
\end{abstract}

\section{Pendahuluan}

Analisis Situasi

Menurut Muhamad Takari, manajemen adalah kegiatan mengelola atau mengurus sesuatu keperluan manusia. Dapat berbentuk sederhana seperti yang dilakukan oleh ibu-ibu rumah tangga dalam mengelola keuangan keluarga, bisa pula berbentuk lebih kompleks seperti seorang pengusaha dempe mengelola usahanya yang melibatkan banyak orang. Atau perusahaan yang lebih besar, seperti Perusahaan Terbatas Perkebunan Negara (PTPN) yang melibatkan ribuan pekerja atau buruh, mandor, kepala bagian, kepala cabang, asisten, direksi, dewan komisaris, dan seterusnya dengan sejumlah permasalahan yang kompleks.

Dalam bidang kesenian juga demikian. Barangkali bagi pekerja seni yang masih baru, memungkiankan menjalankan secara sendirian. Sebut saja misalnya, seorang pelukis, setelah lukisan produksinya maju, maka ia membutuhkan orang lain sebagai staf atau pembantunya, misalnya pembuat bingkai dan kanvas. Kemudian setelah itu, jika ia dikenal secara meluas baik nasional atau intemasional, ia segera memerlukan manajer yang dapat mengatur produksi jenis apa dan kepada siapa harus dijual atau dilelang. Manajer ini akan mencari semua peluang bisnis seni. Ia akan membentuk jaringan di tingkat global, dengan galeri-galeri intemasional yang memiliki nama. 
Sehingga manajemennya lebih kompleks dibanding ketika ia masih awal merintis karimya sebagai seniman seni rupa.

Demikian juga dengan manajemen pertunjukan seni. Ada dua pemahaman yang menyatu dalam sebuah sistem, yaitu manajemen yang dapat diartikan sebagai cara mengelola, dan pertunjukan yang berkaitan dengan produksi dengan materi kesenian atau dapat juga dalam pengertian yang luas sebagai daya untuk mengekspresikan seni untuk masyarakatnya.

Dalam pelaksanaannya, maksud, tujuan, dan sasaran pertunjukan seni perlu dirumuskan dengan matang agar pertunjukan seni dapat berjalan secara optimal. Perumusan tersebut meliputi: Menjelaskan maksud dan tujuan pertunjukan seni, menjelaskan perubahan dan manfaat apa yang didapat dengan adanya pertunjukan seni, mengapa kumpulan kegiatan tersebut perlu dikelola sebagai pertunjukan seni.

Dalam rangka mengelola pertunjukan seni ini, manusia yang terlibat di dalamnya perlu sebuah sistem pengelolaan, agar proses keberlangsungan dari pertunjukan dari awal sampai akhir dapat berjalan secara teratur, terarah, terpadu dan mencapai sasaran. Oleh karena itulah diperlukan pengelolaan atau manajemen.

\section{Permasalahan Mitra}

Permasalahan utama yang menjadi alasan dilaksanakan pelatihan manajemen seni pertunjukan ini karena sejauh yang dapat dilihat di lingkungan Fakultas Ilmu Budaya, terutama mahasiswa dan ormawa, seringkali melaksanakan kegiatan seni. Namun beberapa kegiatan yang dilakukan tidak dimenej dengan baik dalam kerangka manajemen seni pertunjukan.

Padahal kita ketahui bersama, keberlangsungan setiap acara atau pertunjukan, tidak akan terjadi begitu saja selain daripada dimenej dengan sebau system atau organisasi yang tersktruktur. Sehingga capaian atau sasaran dari acara yang digelar dapat tercapai dari segala aspek yang melingkupinya. Untuk itulah diperluksan sekali manajemen seni pertunjukan yang meliputi perencanaan, pengorganisasian, pengarahan, pengendalian dan pengawasan.

Dengan dilakukan pelatihan ini yang meliputi pemberian materi sekaligus akan mendampingi dalam praktek yang akan digelar oleh mitra yakni peluncuran album musikalisasi puisi karya komunitas Kesara.

\section{Metode Pelaksanaan}

Kegiatan Ibm ini dilaksanakan bekerjasama dengan Komunitas Kesara dan beberapa mahasiswa Fib Unilak. Sosialisasi ini meliputi kegiatan pemarapan dan juga pendampingan ketika praktik pergelaran dilaksanakan.

Pelaksanaan kegiatan meliputi beberapa tahap sebagai berikut:

Pemberian dan pemaparan materi tentang ilmu manajemen seni pertunjukan. Pada tahap ini, tim pengabdian FIB Unilak akan memaparkan materi manajemen seni pertunjukan kepada mitra. Menjelaskan apa itu manajemen seni pertunjukan, fungsi, mekanisme, proses dan pentingnya manajemen seni pertunjukan. Mendampingi mitra praktik menggelar acara pertunjukan, mulai dari persiapan atua perencanaan sampailah kepada hari pertunjukan. 


\section{Hasil dan Luaran yang Dicapai}

\section{Hasil}

Kegiatan pelatihan ini dilaksanakan sebulan menjelang peluncuran album yang akan dilaksanakan oleh komunitas Kesara, tepatnya pada tanggal 16 Mei 2021. Bertempat di Studio Seni Sagara Fakultas Ilmu Budaya Unilak. Dihadiri oleh seluruh personil Kesara sebanyak 7 orang dan ditambah 4 orang mahasiswa FIB Unilak yang akan ditempatkan sebagai kru di dalam pelaksanaan peuluncuran album komunitas Kesara tersebut.

Kegiatan pelatihan berlangsung selama setengah hari, mulai dari pukul 08:00 WIB sampai dengan pukul 17:00 WIB. Adapun materi yang diberikan berupa perbekalan terkati dengan Menjelaskan apa itu manajemen seni pertunjukan, fungsi, mekanisme, proses dan pentingnya manajemen seni pertunjukan.

Dalam pemaparan tersebut juga dijelaskan aspek-aspek dari manajemen seni pertunjukan yang meliputi perencanaan, pengorganisasian, pengarahan, pengendalian dan pengawasan. Kelima materi inilah yang kemudian diharapkan kepada peserta pelatihan untuk diaplikasikan dalam acara yang hendak mereka laksanakan pada tanggal 15 Juni 2021. Artinya, usai pelatihan ini, seluruh personil diarahkan dan didampingi oleh narasumber untuk melaksanakan aspek dari manajemen seni pertunjukan yang telah diberi secara teoritis. Mereka dibantu dengan empat orang peserta lainnya, untuk menyusun kelengkapan baik secara adminsitrasi sampai pertunjukan berlangsung.

Mulai dari menyusun struktur manajemen seni pertunjukan, mencari dana, menentukan jemputan, mengirim undangan jemputan, menyusun rangkaian acara, mencari tempat pertunjukan sampailah kepada konsep materi pertunjukan berserta set dekorasi. Selama sebulan, tim mereka kemudian menyiapkan segala sesuatu terkait dengan pertunjukan mereka, didampingi oleh narasumber.

Secara teoritis, pelatihan yang digelar berjalan lancar, hal itu dapat dilihat dari hasil pre test dan pos test yang dibagikan kepada mitra.

Tabel 1. Rekapitulasi Hasil Pre-Test

\begin{tabular}{|l|l|c|c|}
\hline No & \multicolumn{1}{|c|}{ Topik Test } & Ya & Tidak \\
\hline 1 & $\begin{array}{l}\text { Pengetahuan tentang seni } \\
\text { pertunjukan }\end{array}$ & 11 & 0 \\
\hline 2 & $\begin{array}{l}\text { Pengetahuan tentang Manajemen } \\
\text { seni Pertunjukan }\end{array}$ & 1 & 10 \\
\hline 3 & Pengetahuan tentang perencanaan & 1 & 10 \\
\hline 4 & $\begin{array}{l}\text { Pengetahuan tentang } \\
\text { pengorganisasian }\end{array}$ & 1 & 10 \\
\hline 5 & Pengetahuan tentang pengarahan & 1 & 10 \\
\hline 6 & Pengetahuan tentang pengawasan & 1 & 10 \\
\hline
\end{tabular}

Berdasarkan tabel di atas, menunjukkan bahwa mitra sangat mengetahui apa yang dimaksud dengan seni pertunjukan, tapi tidak banyak yang tahu, bagaimana manajemen seni pertunjukan diberlakukan dalam sebuah pertunjukan seni agar pertunjukan berjalan sesuai dengan yang direncanakan sejak awal.

Berbeda dengan setelah dikasih pelatihan, seperti tertuang di dalam pos test berikut ini: 
Tabel 2. Rekapitulasi Hasil Post-Test

\begin{tabular}{|c|l|c|c|}
\hline No & \multicolumn{1}{|c|}{ Topik Test } & Ya & Tidak \\
\hline 1 & $\begin{array}{l}\text { Pengetahuan tentang seni } \\
\text { pertunjukan }\end{array}$ & 11 & 0 \\
\hline 2 & $\begin{array}{l}\text { Pengetahuan tentang Manajemen } \\
\text { seni Pertunjukan }\end{array}$ & 11 & 0 \\
\hline 3 & $\begin{array}{l}\text { Pengetahuan tentang } \\
\text { perencanaan }\end{array}$ & 11 & 0 \\
\hline 4 & $\begin{array}{l}\text { Pengetahuan tentang } \\
\text { pengorganisasian }\end{array}$ & 11 & 0 \\
\hline 5 & Pengetahuan tentang pengarahan & 11 & 0 \\
\hline 6 & $\begin{array}{l}\text { Pengetahuan tentang } \\
\text { pengawasan }\end{array}$ & 11 & 0 \\
\hline
\end{tabular}

Tabel di atas menunjukkan mitra sudah memahami aspek-aspek yang terdapat di dalam manajemen seni pertunjukan. Tinggal lagi bagaimana aspek tersebut langsung diaplikasikan ke pertunjukan yang akan digelar oleh komunitas Kesara.

Tiga minggu setelahnya, setelah melewati perisapan acara, didampingi oleh narasumber, acara peluncuran album musikalisasi puisi Kesara bertajuk "Sehidang Nandung Berkisah" sukses diselenggarakan di Sultan Resto yang beralamat di jalan Ronggowarsito-Pekanbaru. Acara dilaksanakan pada hari Jumat, 15 Juni 2021. Tamu undangan yang hadir sebanyak 50 orang dari kalangan Perusahaan, mahasiswa, dosen, pejabat dan seniman budayawan. Bahkan yang meluncurkan album musikalisasi puisi Kesara, langsung diluncurkan oleh PJ Sekretaris Daerah Provinsi Riau, Drs. H Masrul Kasmi, M.Si.

Dari hasil pendampingan dan evaluasi yang didapat usai acara peluncuran, tim yang merupakan mitra dari pelatihan ini menjalankan aspek dari manajemen seni pertunjukan yang telah diberikan, sangat baik. Hal itu terbukti dari tamu undangan yang hadir, dana yang mereka peroleh dari sponsor, rangkaian acara yang digelar pun terbilang sukses.

\section{Luaran yang Dicapai}

Luaran yang dicapai dari pelatihan ini adalah Komunitas Kesara dan perwakilan mahasiswa FIB Unilak mengerti dan paham tentang Manajemen Seni Pertunjukan. Para peserta menjadi mengerti, bahwa setiap pertunjukan yang dipentaskan, tidak mengalir begitu saja melainkan dengan adanya system manajemen yang baik sejak awal perencanaan sampailah kepada pertunjukan.

Hasil pengetahuan yang didapat pada pelatihan ini, tentu diharapkan dapat disebarluaskan kepada rekan-rekan mahasiswa yang lainnya. Karena secara umum, apa yang telah mereka lakukan dalam praktik langsung dari pelatihan ini, dinilai sangat bagus.

\section{Kesimpulan dan Saran}

\section{Kesimpulan}

Tidak dapat tidak, dikatakan bahwa manajemen seni pertunjukan merupakan pengetahuan yang sangat diperlukan bagi insan-insan seni dan budaya. Karena hal ini mencakup bagaimana mengorganisir segala hal yang terkait dengan sebuah komunitas seni budaya. Mulai dari memenej 
keanggotaan, struktur, dana, sampai kepada hal-hal yang terkait dengan pertunjukan dan keperluannya.

Dari pelatihan inilah hal itu dapat disimpulkan. Mitra yang menjadi peserta dari pelatihan melaksanakan acara peluncuran album musikalisasi puisi ini berjalan sukses. Tahap demi tahap mereka lakukan. Dapat dikatakan, suksesnya acara yang mereka gelar, adalah hasil kerja mereka bersama tim yang mereka bentuk sendiri sejak selesai pelaksanaan pelatihan yang telah diberikan.

Dengan demikian, mitra tidak hanya berkarya tetapi juga mereka mampu memenej kegiatan seni pertunjukan dengan sangat baik. Bahkan mereka mendapat sponsor dan bantuan dari berbagai pihak, seperti PT CPI dan juga dari POLDA Riau. Itu membuktikan bahwa, kreatifitas seni yang mereka lakukan sesungguhnya dapat dikemas ke dalam seni pertunjukan yang dapat diapresiasi oleh masyarakat luas.

\section{Saran}

Dari kesimpulan di atas, dapat disarankan beberapa hal, diantaranya:

1. Upaya kerjasama dengan berbagai pihak untuk melakukan penelitian dan pengabdian budaya sangat diperlukan.

2. Pengetahuan tentang manajemen seni pertunjukan juga menjadi bagian penting untuk dipelajari mahasiswa dalam rangka mewujudkan seni pertunjukan yang berkualitas.

Memicu mahasiswa untuk berkarya dan menjalin kerjasama dengan pihak luar dalam rangka ikut mempublikasikan karya-karya seni budaya Melayu kepada masyarakat.

\section{Daftar Pustaka}

Takari Muhammad. (2008). Manajemen Seni Pertunjukan. Studia Kultura. Fakultas Sastra, Universitas Sumatera Utara

Permas Achsan Dkk. (2003). Manajemen Organisasi Seni Pertunjukan. PPM. Jakarta. 